\title{
Assessment of an Interactive Digital Book at a Vocational School in Indonesia
}

\author{
Patni Ninghardjanti ${ }^{1 *}$, C. Dyah Sulistyaningrum ${ }^{2}$, Andre N. Rahmanto ${ }^{3}$, \\ and Chairul Huda Atma Dirgatama ${ }^{4}$ \\ 1,2,3,4 Office Administration Education, Teacher Training and Education Faculty, \\ Sebelas Maret University \\ *Email: buning@fkip.uns.ac.id
}

\begin{abstract}
Due to advancements in information technology, digital books (i.e., books published in digital form) are becoming increasingly used in the field of education, especially in Indonesia. Although previous studies have focused on the advantages of using digital books in educational activities, such as influencing users to read the materials more frequently and providing the flexibility to read the materials on compatible devices, some users only read certain sections, instead of the entire text. Therefore, the purpose of this study is to assess an interactive digital book (based on the ePub format) at a vocational school in Indonesia, with specific focus on its media aspects, presentation materials, and benefits. Based on the results of the descriptive and statistical analyses, the digital book effectively supported the students' vocational learning activities. Moreover, on average, $95 \%$ of the students agreed with the digital book's media aspects, $97 \%$ agreed with its presentation materials, and $99 \%$ agreed with its benefits. The implication of the findings is that digital books can be effective tools for acquiring information and teaching vocational skills.
\end{abstract}

Keywords: interactive digital book, ePub format, vocational school, information technology

\section{Introduction}

Due to advancements in information technology, digital books (i.e., books published in digital form) are becoming increasingly used in the field of education. In Indonesia, digital books have been slowly replacing printed ones, as the main tools for acquiring information and teaching various skills. This has occurred for several reasons: 1) The difficulty of obtaining conventional printed books; 2) The development of information technology that can support digital books; and 3) The need to obtain affordable books as quickly as possible (Andina, 2012).

Previous studies have focused on the advantages of using digital books in the field of education. For instance, Fasimpaur (2004) revealed that, since learners consider digital books as "new and unique media," they tend to read the learning materials more frequently than conventional textbooks. Moreover, Doty, Popplewell, and Byers (2001) stated that reading texts on computer screens (or compatible devices) is more effective than reading the same information in textbooks. Conversely, one of the disadvantages of using digital books is that users tend to read certain sections, instead of the entire text (Hernon, Hooper, Leach, Saunders, \& Zhang, 2007). Therefore, the purpose of the present study is to assess an interactive digital book (based on the ePub format) at a vocational school in Indonesia, with specific focus on its media aspects, presentation materials, and benefits.

\section{Research Method}

\subsection{Research Design}

This descriptive quantitative study uses the survey method to explain the relationship between the aforementioned variables. It also statistically analyzes the numerical data based on the participants' responses.

\subsection{Participants}

The participants in this study consisted of 123 students at the SMK Eks-Karesidenan Surakarta vocational school in Indonesia.

\subsection{Data Collection}

Data collection was performed by using self-reported questionnaires with close-ended questions.

\subsection{Data Analysis}

A descriptive analysis was performed as the first step for conducting the statistical analysis. It also helped identify the associations among the aforementioned variables. 


\section{Results and Discussion}

\subsection{Interactive Digital Book}

The interactive digital book in this study is based on the Interpol ePub format, which has proven to be effective for vocational learning activities.

\subsection{Field Trial}

This study focuses on three aspects of the interactive digital book: its media aspects, presentation materials, and benefits.

\subsubsection{Media Aspects}

Table 1. Assessment of the Interactive Digital Book's Media Aspects

\begin{tabular}{|c|c|c|c|c|}
\hline Media Aspects (\%) & $\begin{array}{c}\text { Strongly } \\
\text { Agree }\end{array}$ & Agree & Disagree & $\begin{array}{c}\text { Strongly } \\
\text { Disagree }\end{array}$ \\
\hline Sentence Clarity & 81 & 8 & 8 & 2 \\
\hline Supporting Media Clarity & 75 & 18 & 6 & 2 \\
\hline Gives Interest to Students & 93 & 5 & 2 & 1 \\
\hline Conformity Example & 94 & 6 & 0 & 0 \\
\hline
\end{tabular}

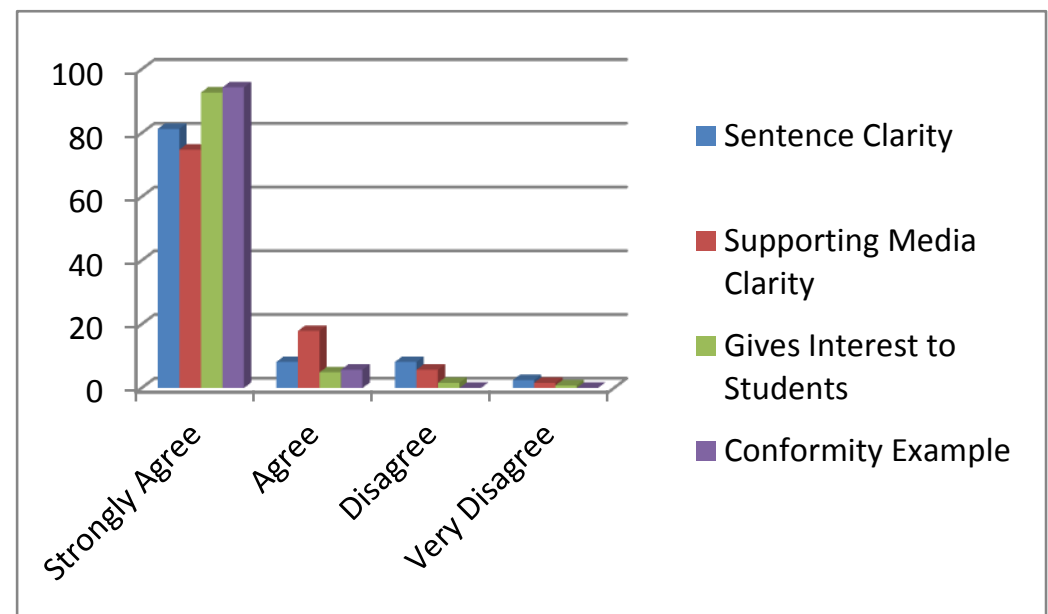

Figure 1. A Graph of the Students' Responses regarding the Interactive Digital Book's Media Aspects

Based on Table 1 and Figure 1, "Conformity Example" and "Gives Interest to Students" received the highest ratings among the students that strongly agreed/agreed with these items (i.e., 100\% and 98\%, respectively). Meanwhile, "Supporting Media Clarity" and "Sentence Clarity" received slightly lower ratings of 93\% and $90 \%$, respectively.

\subsubsection{Presentation Materials}

Table 2. Assessment of the Interactive Digital Book's Presentation Materials

\begin{tabular}{|c|c|c|c|c|}
\hline Presentation Materials (\%) & $\begin{array}{c}\text { Strongly } \\
\text { Agree }\end{array}$ & Agree & Disagree & $\begin{array}{c}\text { Strongly } \\
\text { Disagree }\end{array}$ \\
\hline Ease in Understanding the Materials & 89 & 9 & 2 & 0 \\
\hline Sentence Clarity & 85 & 12 & 3 & 0 \\
\hline Example Clarity & 90 & 7 & 2 & 1 \\
\hline
\end{tabular}




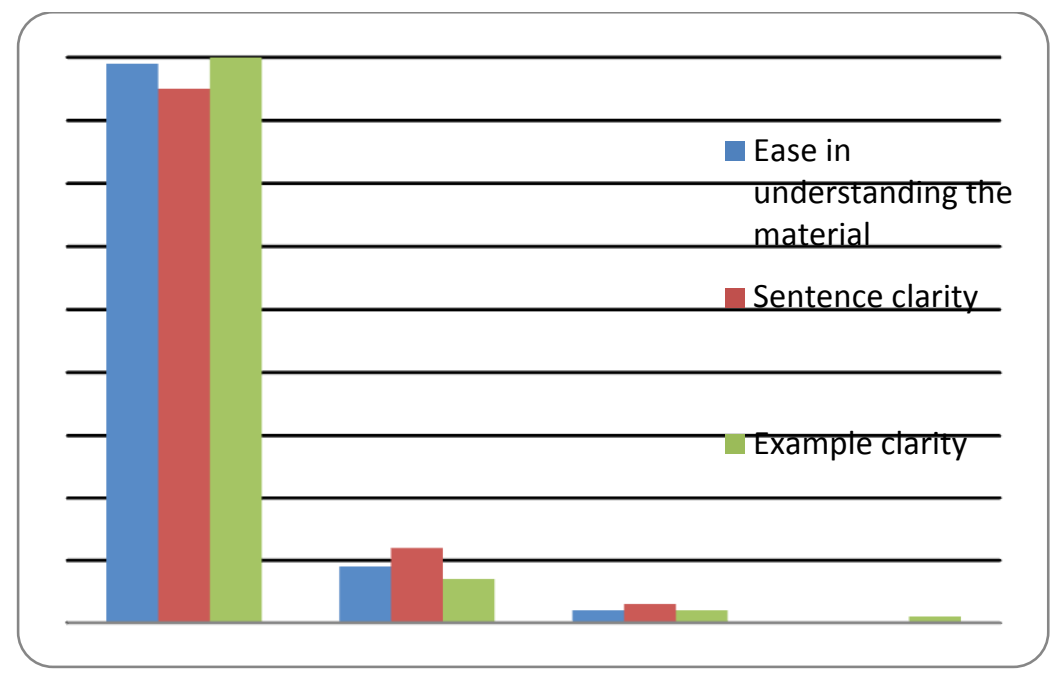

Figure 2. A Graph of the Students' Responses regarding the Interactive Digital Book's Presentation Materials

Based on Table 2 and Figure 2, "Ease in Understanding the Materials," "Sentence Clarity," and "Example Clarity" received the highest ratings among the students that strongly agreed/agreed with these items (i.e., 98\%, $97 \%$, and $97 \%$, respectively.

Table 3. Assessment of the Interactive Digital Book's Benefits

\begin{tabular}{|c|c|c|c|c|}
\hline Benefits (\%) & $\begin{array}{c}\text { Strongly } \\
\text { Agree }\end{array}$ & Agree & Disagree & $\begin{array}{c}\text { Strongly } \\
\text { Disagree }\end{array}$ \\
\hline Ease of Learning & 93 & 6 & 1 & 0 \\
\hline Interest in Using Media & 95 & 5 & 0 & 0 \\
\hline Increased Motivation to Learn & 97 & 2 & 1 & 0 \\
\hline
\end{tabular}

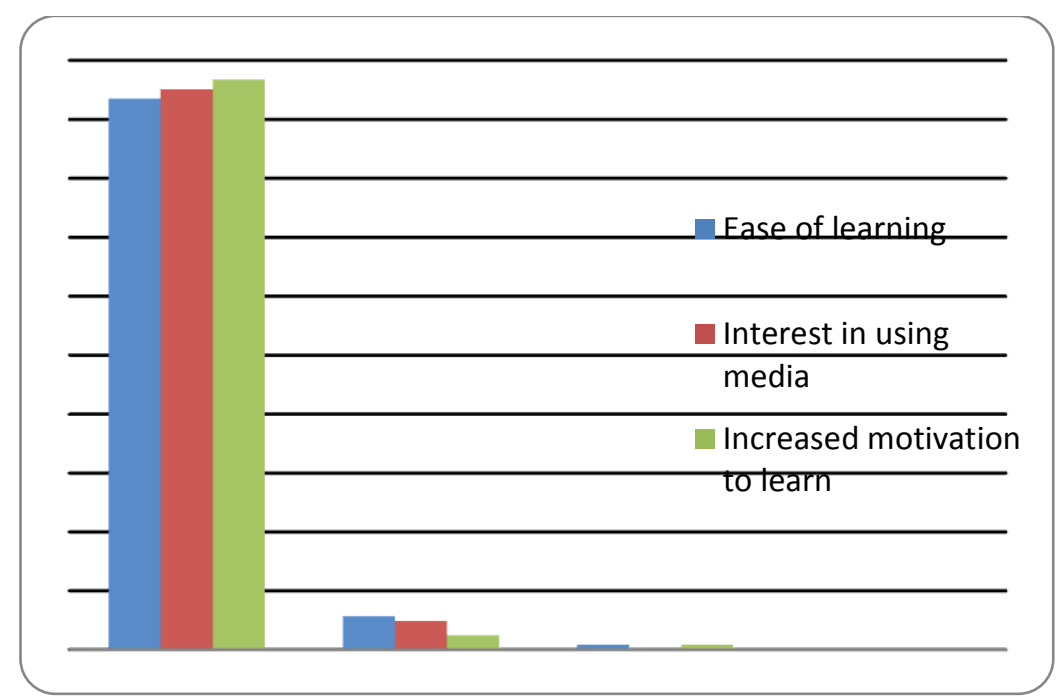

Figure 3. A Graph of the Students' Responses regarding the Interactive Digital Book's Benefits

Based on Table 3 and Figure 3, "Interest in Using Media," "Ease of Learning," and "Increased Motivation to Learn" received the highest ratings among the students that strongly agreed/agreed with the items (i.e., 100\%, $99 \%$, and $99 \%$, respectively).

It is important to note two limitations of this study. First, this study was only conducted at a single vocational school in Indonesia. Second, this study only utilized a relatively small sample of students. Thus, future studies should include other vocational schools in the country and expand the number of students in order to generalize the results. 


\section{Conclusion}

This study assessed an interactive digital book at a vocational school in Indonesia, with specific focus on its media aspects, presentation materials, and benefits. Based on the results of the descriptive and statistical analyses, this interactive digital book effectively supported the vocational learning activities. Moreover, among these aspects, an average of $95 \%$ of the students agreed with the book's media aspects, $97 \%$ agreed with its presentation materials, and $99 \%$ agreed with its benefits. The implication of the findings is that digital books can be effective tools for acquiring information and teaching vocational skills.

\section{Acknowledgment}

The authors wish to thank the teachers and administration of SMK Eks-Karesidenan Surakarta vocational school, all of whom attended the Subject-Teacher Discussion (MGMP).

\section{References}

Andina, E. (2012). Buku digital dan pengaturannya. Jurnal Aspirasi, 2(1), 79-95.

Arikunto, S., \& Suatu Pendekatan Praktek, P. P. (2008). Cetakan. Ketigabelas. Jakarta: P T. Rineka Cipta.

Chen, C. (2013). Perkembangan industri buku di Masa Depan. Retrieved from https://marketing.co.id/perkembangan-industri-buku-di-masa-depan/.

Doty, D. E., Popplewell, S. R., \& Byers, G. O. (2001). Interactive CD-ROM storybooks and young readers' reading comprehension. Journal of Research on Computing in Education, 33(4), 374-384. doi: 10.1080/08886504.2001.10782322.

Fasimpaur, K. (2004). E-books in schools: Check out the reasons why e-books are gaining popularity in K-12 schools. Media and Methods, 40(5), 12.

Hernon, P., Hopper, R., Leach, M. R., Saunders, L. L., \& Zhang, J. (2007). Ebook use by students: Undergraduates in economics, literature, and nursing. The Journal of Academic Librarianship, 33(1), 3-13. doi: $10.1016 /$ j.acalib.2006.08.005.

Ismail, R., \& Zainab, A. N. (2005). The pattern of e-book use amongst undergraduates in Malaysia: A case of to know is to use. Malaysian Journal of Library and Information Science, 10(2), 1-23.

Sugiyono (2010). Metode penelitian Pendidikan Pendekatan Kuantitatif, kualitatif, dan R\&D. Bandung: Alfabeta. 